\title{
MANDATING THE GARDASIL VACCINE: A Constitutional ANALYSIS
}

Kyra R. Wagoner*

TABLE OF CONTENTS

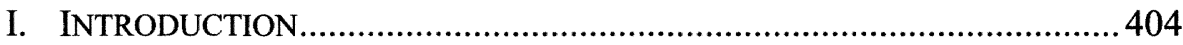

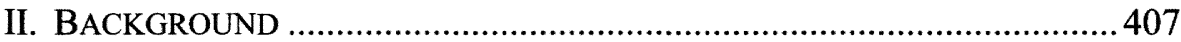

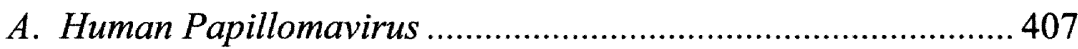

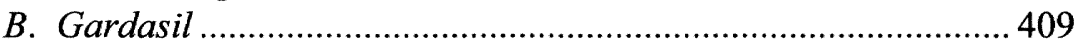

III. IT IS CONSTITUTIONAL FOR STATES TO MANDATE THE GARDASIL

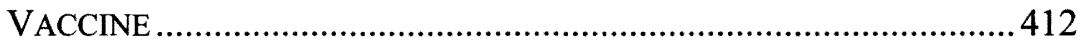

A. Cases Establishing States' Authority to Mandate

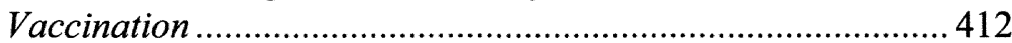

B. Application of Jacobson Today ................................................... 415

1. An "All or Nothing" Approach is Not the Best Approach to Take When Thousands of Lives May be Saved by the Vaccine in the United States

2. Since Safety Concerns and Myths Have Been Addressed, the Number of Vaccines Children Currently Receive Should Not Detract From the Fact That Gardasil Could Save Thousands of Lives

3. Regardless of the Fact That HPV Could be Reduced Through Behavior Modification, Gardasil Should be Viewed in the Same Light as the Vaccine for Hepatitis $B$.

4. Mandating Gardasil Will Not Encourage Children to Engage in Sexual Activity

5. Mandating Gardasil is in the Child's Best Interest

6. States Should Mandate Gardasil to Ensure that the

Vaccine's Cost is Covered so that the Highest

Number of Females Have Access to the Vaccine.

7. Vaccination Programs Save Money in the Long-Run 424

8. Mandatory Vaccination Programs Ensure Universal Coverage Thereby Creating the Most Effective Way to Prevent Diseases Such as HPV and Cervical Cancer.

9. Many States Have Begun Measures to Mandate Gardasil. 
IV. IT IS CONSTITUTIONAL FOR THE STATE TO DENY PARENTS' RELIGIOUS AND PHILOSOPHICAL EXEMPTIONS TO THE GARDASIL

VACCINE 428

A. Cases Discussing Exemptions to Vaccinations ......................... 428

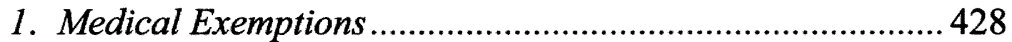

2. Philosophical Exemptions................................................. 429

3. Religious Exemptions ........................................................... 429

B. It is Constitutional for the State to Deny Parents

Non-Medical Exemptions to the Gardasil Vaccine .................. 431

V. CONCLUSION. 435

\section{INTRODUCTION}

Vaccinations were developed in the late eighteenth century to prevent smallpox. ${ }^{1}$ Since then, vaccinations have become an important component of public health efforts and the most cost-effective and widely-used public health measure to control the spread of epidemic diseases such as smallpox, measles, mumps, rubella, diphtheria, and polio. ${ }^{2}$ When the Centers for Disease Control and Prevention ("CDC") published a list of the great public health achievements for the United States from 1900 to 1999, vaccination was the first achievement listed. ${ }^{3}$

* J.D. Candidate, 2008, Indiana University School of Law- Indianapolis; B.S., 2002, Butler University.

1. James G. Hodge, Jr. \& Larence O. Gostin, School Vaccination Requirements: Historical, Social, and Legal Perspectives, 90 KY. L.J. 831, 833 (2002). See also Rick Westhead, Imagine, a Vaccine, TORONTO STAR, Aug. 12, 2006, at F1 (It was Dr. Edward Jenner who first, noticed that dairymaids who had come down with cowpox from cows appeared to be immune from catching smallpox.... On May 19, 1796, Jenner scratched the arm of a local boy and dropped in rivulets of cowpox pus he had taken from a blister on the hand of a dairy worker. Several months later, Jenner scratched the boy's arm with deadly pus he had taken from a smallpox victim. The boy didn't get sick and Jenner published the results of the [first] successful vaccination.

Id. Interestingly, the word vaccination is rooted in the Latin word vacca which means cow.).

2. Hodge, Jr. \& Gostin, supra note 1, at 833. The extensive use of vaccines has eradicated smallpox worldwide and has eliminated wild-type polio from the Western Hemisphere. As a result, smallpox vaccination has been discontinued. According to the World Health Organization, the eradication of polio could occur in 2007. Andrew Zoltan, Note, Jacobson Revisited: Mandatory Polio Vaccination as an Unconstitutional Condition, 13 GEO. MASON L. REV. 735,735 (2005).

3. Nat'l Immunization Program, CDC, Achievements in Public Health, 1900-1999: Impact of Vaccines Universally Recommended for Children - United States, 1990-1998, 48 MORBIDITY \& MORTALITY WKLY. REP. 243, 243-48 (1999), available at http://www.cdc.gov $/ \mathrm{mmwr} /$ preview/mmwrhtml/ 00056803.htm (last visited Mar. 20, 2008). 
Vaccination programs are supported by state legal requirements as well as federal funding and oversight. ${ }^{4}$ Every state has mandatory vaccination laws that require children attending schools to be vaccinated prior to enrollment, unless they are eligible for various medical, religious, or philosophical exemptions. ${ }^{5}$ Children that have not been vaccinated may not be permitted to attend school, and the parents or guardians who failed to vaccinate them may be subject to civil fines, and criminal penalties, though rarely applied, may be imposed against them. ${ }^{6}$

Although incidents of communicable disease among children have significantly decreased since the implementation of mandatory vaccination laws, strong opposition from parents and "antivaccinationists" still exists. ${ }^{7}$ Mandatory vaccination programs have been challenged as: "(1) inconsistent with the federal constitutional principles of individual liberty and due process, (2) an unwarranted governmental interference with individual autonomy, and (3) an infringement of personal religious beliefs under the First Amendment." over, some opponents of mass vaccinations also fear harmful effects arising from the introduction of foreign particles into the body, while others believe that vaccinations actually spread disease. ${ }^{9}$

The debate grew more intense in June of 2006 when the Food and Drug Administration ("FDA") approved the use of Gardasil. ${ }^{10}$ Gardasil is the first vaccine for females that prevents against four strains of the human papillomavirus ("HPV"), which can cause genital warts and lead to cervical cancer. " HPV is the most common sexually transmitted disease ("STD") in the United States with approximately 6.2 million people acquiring HPV annually. ${ }^{12}$ Moreover, cervical cancer is the second leading cause of cancer deaths in women, claiming 270,000 lives annually worldwide, including 3700 deaths in the United States. ${ }^{13}$ In order for Gardasil to be one hundred percent effective in preventing the genital warts and cervical cancer caused by certain types of HPV, a woman must not have been exposed to the virus previously. ${ }^{14}$ Accordingly, the FDA "has

4. Hodge, Jr. \& Gostin, supra note 1 , at 833.

5. Id.

6. Id.

7. Id. at 834 .

8. Id.

9. Id.

10. See generally MERCK \& Co., INC., GARDASIL InFORMATIONAL PAMPHLET (2006) [hereinafter GARDASIL PAMPHLET] (Gardasil's scientific name is Quadrivalent Human Papillomavirus (Types 6, 11, 16, 18) Recombinant Vaccine.).

11. Maureen Killackey, Facts About HPV Vaccine Need to be Clarified, ALBANY TiMES UNION, July 6, 2006, at A10 [hereinafter Killackey].

12. CTR's For Disease Control \& Prevention U.S. Dep'T of Health \& Human SERVICES, HPV VACCINE QUESTIONS AND ANSWERS (2006), http://www.cdc.gov/std/ hpv/STDFact-HPV-vaccine.htm [hereinafter CDC, HPV ANSwERS] (last visited Mar. 20, 2008).

13. Editorial, Major Breakthrough in Women's Health, GRAND RAPIDS PRESS, Aug. 29, 2006, at A8 [hereinafter Major Breakthrough].

14. Killackey, supra note 11, at A10. 
approved Gardasil's use for females age 9 to $26,{ }^{, 15}$ and the CDC has recommended that the Gardasil vaccination be made available to women ages eleven to twenty-six years. ${ }^{16}$

These facts and their social implications have startled many parents. The Family Research Council and Focus on the Family, both conservative Christian organizations with strong evangelical Christian affiliations, oppose "anything they believe promotes premarital sex." 17 Additionally, many "[p]ro-family groups are united in believing that parents should decide what is best for their children." to force an individual to do something simply because it is potentially beneficial. ${ }^{19}$ In support of this statement, Linda Klepacki, a sexual health analyst at Focus on the Family, commented: "We support widespread distribution of the vaccine, but we oppose mandatory vaccination." ${ }^{20}$ Similarly, Moira Gaul, a policy analyst for the Family Research Council, stated: "Instead of requiring mass vaccination, the government should allow parents to be the primary decision maker for their children's health, and parents should receive all of the information on the vaccine's risks and benefits to be able to make an educated decision ...."21 Since several groups feel that mandating Gardasil is an infringement on children's and parents' freedoms, it is important to examine the public health benefits derived from the vaccine before making a decision as to whether HPV vaccinations should be mandatory. ${ }^{22}$

This Note will first detail the startling statistics on HPV and describe what the Gardasil vaccine entails. Next, this Note will examine cases that have upheld a state's power to mandate vaccination, as well as cases that have warranted exemptions to vaccination. This Note will then conclude with an argument that it is constitutional for states to mandate that girls receive the Gardasil vaccination prior to entering school due to the overwhelming public health benefits the vaccine provides. The argument will also explain that it is not constitutionally required for states to provide non-medical exemptions to the Gardasil vaccination.

15. Major Breakthrough, supra note 13, at A8.

16. Eric Ladley, Political Pressure Could Limit Gardasil, 25 Med Ad News 8, Aug. 1, 2006, at 10 [hereinafter Ladley].

17. John Simons, Merck's \$4 Billion PR Problem, ForTUNE, June 5, 2006, http://money.cnn.com/2006/06/02/news/companies/pluggedin_fortune/index.htm [hereinafter Simons] (last visited Mar. 20, 2008).

18. Peter Sprigg, Op. Ed., A Promising Vaccine...but Gardasil Should Not be Mandatory, WASH. TIMES, July 17, 2006, at A17 [hereinafter Sprigg].

19. See id.

20. Cheryl Wetzstein, 1 st HPV Vaccine $O K^{\prime}$ 'd, WASHINGTON TimES, July 18,2006 , at A2.

21. Ladley, supra note 16 , at 10.

22. Hodge, Jr. \& Gostin, supra note 1, at 834. 


\section{BACKGROUND}

\section{A. Human Papillomavirus}

A common misconception of HPV is that it can only be spread through sexual intercourse. Indeed, HPV can be spread by contact with the scrotum, vagina, penis, or anus. ${ }^{23} \mathrm{HPV}$ can, however, also be transmitted through skinto-skin contact. ${ }^{24}$ Recently, a scientist even discovered HPV under the fingernails of young men. ${ }^{25}$ Dr. Laura Koutsky, an epidemiologist at the University of Washington, stated, "The presence of HPV under fingernails at the very least suggests another possible route of transmission .... It's an additional route of infection. $" 26$

In 2000, the Henry J. Kaiser Family Foundation conducted a survey in which seventy percent of American adults said that they had never heard of $\mathrm{HPV},{ }^{27}$ even though HPV is the most common sexually transmitted disease in the United States. ${ }^{28}$ At least one-half of all sexually active people will get HPV at some time in their lives. ${ }^{29}$ Each year, approximately 6.2 million new HPV infections occur in the United States alone. ${ }^{30} \mathrm{HPV}$ is most common in young women and men who are in their late teens and early twenties. ${ }^{31}$ Of the approximately six million new cases of HPV in the United States every year, it is estimated that seventy-four percent of them occur in fifteen to twenty-four year olds. ${ }^{32}$ However, eighty percent of women will contract HPV by the age of fifty. ${ }^{33}$

There are more than a hundred types of HPV, most of which are harmless. ${ }^{34}$ Of the many types of HPV, nearly forty types of HPV can infect the genital areas of men and women. ${ }^{35}$ Unlike most HPV types, which cause no

23. See CDC, HPV ANSWERS, supra note 12 .

24. Id.

25. Tom Paulson, New Risks Discovered for HPV Virus Found Under Men's Fingernails, Pointing to More Ways of it Spreading, SEATTLE Post-INTELligenCER, Aug. 1, 2007, at B1.

26. Id. While no evidence exists supporting the contention that someone can get HPV from a handshake, this recent finding of HPV under the fingernails shows that scientists have more to learn about exactly how the virus is transmitted. Id.

27. Wetzstein, supra note 20, at A2.

28. Ayana Mathis, The Ultimate STD Prevention, GLAMOUR, Nov. 2006, at 114 [hereinafter Mathis]

29. CDC, HPV ANSWERS, supra note 12.

30. GARDASIL PAMPHLET, supra note 10.

31. Id.

32. Id.

33. Erin Allday, Cervical Cancer Vaccine Approved: Sexually Transmitted Disease Treatment Raises Ethics Debate, SAN FrANCISCO CHRON., June 9, 2006, at A1.

34. Karl Stark, Trading Shots over a Vaccine: Merck and GlaxoSmithKline are in Fierce Competition to Develop the World's Top Cervical-Cancer Immunization, PHILADELPHIA INQUIRER, July 8, 2007, at C1.

35. CDC, HPV ANSWERS, supra note 12. 
symptoms and go away on their own, HPV types that infect the genital areas can cause genital warts. ${ }^{36}$ Some types of HPV, about fifteen to twenty types, can infect a woman's cervix and cause the cells to change. ${ }^{37}$ Over time, these cell changes can lead to cervical cancer if they are not treated. ${ }^{38}$ "Typically, the length of time from infection with HPV to development of cervical cancer is about 15-20 years. For this reason, although most HPV infections occur in teenagers and young adults, cervical cancer is more common in women in their $40 \mathrm{~s}$ and 50s." 39 In addition to cervical cancer, HPV can also cause cancers of the anus, vagina, vulva, penis, head, and neck. ${ }^{40}$ Finally, mothers can transmit the HPV virus to their baby when it passes through the birth canal during delivery. ${ }^{41}$

Cervical cancer claims 270,000 lives annually worldwide, making it the second leading cause of cancer deaths in women. ${ }^{42}$ Papanicolaou ("Pap") tests have helped cut cervical cancer rates in the United States, but the American Cancer Society reported that in 2006, over 9700 American women were diagnosed with cervical cancer and 3700 American women died from this cancer. ${ }^{43}$ It is projected that cervical cancer will kill more than 4600 women in the United States in $2007 .^{44}$

HPV cannot be cured; however, there are treatments for the health related issues that occur as a result of HPV infection. "Regular Pap tests and followup treatment can prevent most, but not all, cases of cervical cancer;" however, no HPV tests are currently available for men, and diagnosis is therefore problematic if no warts are present. "Pap tests can detect cell changes in the cervix before they turn into cancer," but the tests cannot detect all types of cervical cancers while they are still in curable phase. ${ }^{47}$ However, "[m]ost women diagnosed with cervical cancer in the U.S. have either never had a Pap test, or have

36. Id.

37. Id. See also Stark, supra note 34, at C1.

38. CDC, HPV ANSWERS, supra note 12.

39. The Children's Hosp. of Philadelphia, Vaccine Educ. CTr., A LoOK at Each VACCINE: HUMAN PAPILLOMAVIRUS VACCINE, http://www.chop.edu/consumer/jsp/division/generic.jsp?id=84544 [hereinafter CHILDREN's HOSPITAL, A LOOK AT HPV] (last visited Mar. 20, 2008).

40. CDC, HPV ANSWERS, supra note 12. See also Paulson, supra note 25, at B1.

41. CHILDREN's HosPITAL, A LoOK AT HPV, supra note 39.

42. Major Breakthrough, supra note 13, at A8.

43. CDC, HPV ANSWERS, supra note 12. "The Pap test is performed by scraping off cells from the opening of the cervix and examining them under the microscope to see whether they have begun to show changes consistent with the early development of cancer (called precancerous changes)." CHILDREN's HosPITAL, A LOOK AT HPV, supra note 39.

44. Sandra Scantling, Vaccinating Against HPV Makes Sense, Even for Young Girls, HARTFORD COURANT, July 15, 2007, at H4. It should be noted that one-half of all the cases of cervical cancer occur in low-income and minority women. See, e.g., Editorial, Fighting Cancer in School, L.A. TIMES, Aug. 18, 2006, at B10 [hereinafter Fighting Cancer].

45. CDC, HPV ANSWERS, supra note 12 (Health problems caused by HPV include genital warts, cervical cell changes, and cancers of the cervix, vulva, vagina, and anus).

46. Id.

47. Id. 
not had a Pap test in the last 5 years."48 Thus, the Pap test, though an imperfect tool, is nonetheless an essential weapon in the fight to save women from cervical cancer.

Abstinence is the only sure way to prevent HPV. ${ }^{49}$ Those individuals who are sexually active can reduce their risk by being in a monogamous relationship with someone who has had no other sex partners or by limiting their number of sex partners. ${ }^{50}$ Even someone with only one lifetime sex partner can still contract HPV if his or her partner has had previous partners. ${ }^{51}$ In 2002 , the CDC conducted a study on sexual activity and contraceptive use among teenagers, which revealed that forty-six percent of never-married males and females between the ages of fifteen and nineteen have had sexual intercourse at least once. ${ }^{52}$ Moreover, a quarter of the teenagers who engaged in sexual intercourse did not use any method of contraception. ${ }^{53}$ Based on these statistics, it is evident that parents and the government cannot rely on children remaining abstinent until marriage. The Gardasil vaccine, administered at an early enough age, can at least dramatically reduce the possibility of females contracting HPV and cervical cancer.

\section{B. Gardasil}

On June 8, 2006, the FDA approved the nation's first HPV vaccine, Gardasil. "Gardasil protects against HPV types 16 and 18, which cause approximately 70 percent of cervical cancers and types 6 and 11, which cause approximately 90 percent of genital warts."54 This vaccine, which is produced by Merck \& Co., Inc. could dramatically reduce the incidence of cervical cancer and genital warts in vaccinated women; however, women should still have regular Pap tests to detect the types of HPV that Gardasil does not prevent. ${ }^{55}$

Gardasil will only work for women who have not yet been exposed to certain types of HPV. ${ }^{56}$ Currently, there is no test available to tell if a woman has been exposed to the four HPV types against which Gardasil protects. ${ }^{57}$ Since the vaccine is only effective for women who have not been previously exposed to HPV, the FDA has licensed the vaccine's use for girls and women ages nine to twenty-six. ${ }^{58}$ Also, "[t]he U.S. Centers for Disease Control and Prevention's

48. Id.

49. Id.

50. Id.

51. CDC, HPV ANSWERS, supra note 12.

52. Ctr's for Disease Control \& PREVention, U.S. Dep'T OF Health \& Human Services, Vital \& Health STATistics, ser. 23, no. 24, at 5 (2004), available at http:// www.cdc.gov/nchs/data/series/sr_23/sr23_024.pdf (last visited Mar. 20, 2008).

53. Id. at 9.

54. Killackey, supra note 11 , at A10.

55. Id.

56. Id.

57. CDC, HPV ANSWERS, supra note 12.

58. Major Breakthrough, supra note 13, at A8. 
Advisory Committee on Immunization Practices voted unanimously to recommend that girls and women 11 to 26 years old be vaccinated with Gardasil and that 9-year-old and 10-year-old girls can be vaccinated with Gardasil at the discretion of their physicians." 59 Moreover, some doctors have expressed the opinion that some older women should also be vaccinated. ${ }^{60}$

The Gardasil vaccine does not provide protection against all types of HPV and will not, therefore, impede the development of all types of cervical cancer and genital warts. ${ }^{61}$ "About $30 \%$ of cervical cancers will not be prevented by the vaccine, so it will be important for women to continue getting screened for cervical cancer [through] (regular Pap tests). ${ }^{, 62}$ Furthermore, Gardasil does not inhibit HPV types responsible for about ten percent of genital warts and will not prevent other sexually transmitted infections. ${ }^{63}$

The HPV vaccine is administered in a series of three shots, over a sixmonth period, and costs around $\$ 360$ exclusive of the doctor's fee for administering the inoculation. ${ }^{64}$ Most insurance companies cover the vaccine for females under the age of twenty-seven. ${ }^{65}$ In November of 2006, the CDC added Gardasil to its list of vaccines provided by the federal Vaccines for Children Program. ${ }^{66}$ Through the Vaccines for Children Program, children who are eighteen or younger who are eligible for Medicaid, have no health insurance or are underinsured, or are Native American or Native Alaskan, will be eligible to receive the vaccine for free. ${ }^{67}$ Some states also seek to facilitate the vaccination process for the uninsured or underinsured by providing free or low cost vaccinations at public clinics. ${ }^{68}$

59. Ladley, supra note 16 , at 10.

60. Mathis, supra note 28 , at 114.

61. CDC, HPV ANSWERS, supra note 12.

62. Id.

63. Id.

64. Id. The first dose is administered on a date chosen by the female recipient. The second dose is given two months after the first dose, while the third dose is given six months after the first dose. All three doses are required to receive the vaccine's full benefits. GARDASIL PAMPHLET, supra note 10.

65. Mathis, supra note 28, at 114.

66. Lynn Doan, Schools to Offer STD Vaccine, L.A. TIMES, July 24, 2006, at B3.

67. CTR's For Disease Control \& PREVENTION, U.S. DEP'T OF HEALTH \& HuMaN SERVICES, VACCINES \& IMMUNIZATIONS: VFC: FOR PARENTS (2006), http://www.cdc.gov/ $\mathrm{nip} / \mathrm{vfc} /$ Parent/parent home.htm (last visited Mar. 20, 2008). The Vaccines for Children Program (the "Program") was created by Congress after the outbreak of a measles epidemic in the United States in the late 1980s, an epidemic which resulted in tens of thousands of cases of measles and hundreds of deaths. The Program was funded through the Omnibus Budget Reconciliation Act of 1993. The Program is administered at the national level by the CDC through the National Immunization Program. Currently, vaccines that prevent the following diseases are covered by the Program: diphtheria, haemophilus influenzae type b, hepatitis A, hepatitis B, influenza, measles, meningococcal disease, mumps, pertussis, pneumococcal disease, polio, rotavirus, rubella, tetanus, and varicella. Id.

68. CDC, HPV ANSWERS, supra note 12. 
When a new vaccine becomes available, there is no sure way to estimate the likely duration of its effectiveness. ${ }^{69}$ With regard to the Gardasil vaccine, however, research indicates that women are still protected five years after innoculation. ${ }^{70}$ However, it may be necessary for vaccinated women to receive a booster shot of the vaccine at a later date. ${ }^{71}$

It has still not been determined if Gardasil is effective in males. ${ }^{72}$ It is possible that the vaccination of males would be beneficial in that it might prevent or reduce the incidence of both genital warts and rare types of cancer. ${ }^{73}$ Moreover, vaccinating males might indirectly improve the health of the female population by reducing HPV transmission rates. ${ }^{74}$ Accordingly, studies are now being conducted to determine whether the Gardasil vaccine will "prevent HPV infection and diseases in males." ies now underway, Gardasil could be "licensed and recommended" for males as well as females. ${ }^{76}$

Merck's Gardasil was the first HPV vaccine approved for use by the FDA in the United States, but other companies are currently working on similar vaccines. ${ }^{77}$ GlaxoSmithKline and Medimmune, Inc. are currently developing Cervarix, an alternative to Gardasil, which could be approved in the United States this year. ${ }^{78}$ Cervarix may offer broader cervical cancer protection than Gardasil; however, it will not prevent genital warts. ${ }^{79}$ In an effort to find a cheaper alternative to Gardasil and Cervarix, two researchers in Kentucky are cultivating proteins from tobacco plants that could be used to prevent cervical cancer as well. ${ }^{80}$ Although the tobacco-based vaccine is still in the early stages of development, the researchers estimate that the vaccine would only cost three dollars for three doses. ${ }^{81}$ Thus far, the tobacco-based vaccine has been effective when administered to dogs, and researchers believe the first phase of human clinical trials could start as early as next year. ${ }^{82}$

Clearly, HPV vaccines can save lives and reduce the spread of at least some HPV types. Indeed, given the health benefits and life saving potential of HPV vaccines, like Gardasil, Cerarix, and the tobacco-based version currently in development, states should follow the precedent set in their previous vacci-

69. Id.

70. Id.

71. Id.

72. Id.

73. CDC, HPV ANSWERS, supra note 12.

74. Id.

75. Id.

76. Id.

77. Stark, supra note 34 , at $\mathrm{C} 1$.

78. Id.

79. Mathis, supra note 28 , at 114.

80. Associated Press, Tobacco-Based Drug Studied; Hope for Cervical Cancer Vaccine, KentuCKy Post, July 31, 2007, at A10.

81. Id.

82. Id. 
nation campaigns against diseases such as polio, measles, mumps, rubella, and hepatitis B and make HPV vaccination mandatory.

\section{IT IS CONSTITUTIONAL FOR STATES TO MANDATE THE GARDASIL VACCINE}

\section{A. Cases Establishing States' Authority to Mandate Vaccination}

Federal law does not require the vaccination of children or adolescents. ${ }^{83}$ Under the Public Health Service Act, however, the Secretary of Health and Human Services has the authority to make and enforce regulations necessary "to prevent the introduction, transmission, or spread of communicable diseases from foreign countries into the States or possessions, or from one State or possession into any other State or possession." ${ }^{84}$ Although the Act's language appears to grant broad authority to "prevent the spread of diseases," it neither authorizes the promulgation of federal regulations related to mandatory vaccination programs generally, nor suggests the implementation of mandatory vaccination programs, necessary to prevent or eliminate public health emergencies. ${ }^{85}$ Indeed, the preservation of public health has historically been the responsibility of state and local governments, and the authority to enact laws relevant to the protection of public health is therefore derived from the states' general police powers. ${ }^{86}$ The following cases uphold that tradition.

In Gibbons v. Ogden, Chief Justice John Marshall held that the state's police powers "form a portion of that immense mass of legislation, which embraces every thing within the territory of a state, not surrendered from the general government .... [and] [i]nspection laws, quarantine laws, [and] health laws of every description . . . are component parts of this mass." ${ }^{87}$ This doctrine was emphasized by Justice Miller in the Slaughter-House Cases ${ }^{88}$ where he held that a state statute intended to protect the public health was clearly an example of the state's police power. ${ }^{89}$ Based on this presumption, Miller concluded that if police power was the key to social order, then the preservation of health stood at the core of that power. ${ }^{90}$ No American court, however, contemplated the in-

83. CDC, HPV ANSWERS, supra note 12 .

84. The Public Health Service General Powers and Duties Quarantine and Inspection: Regulations to Control Communicable Diseases, 42 U.S.C. $§ 264$ (2002).

85. Angie A. Welborn, Mandatory Vaccinations: Precedent and Current Laws, in CRS REP. FOR CONG. 2005, at CRS-5 (Cong. Res. Serv., Libr. of Cong., Ord. Code RS21414, 2005).

86. Id. See also People v. Robertson, 134 N.E. 815,817 (1922) ("That the preservation of the public health is one of the duties devolving upon the state as a sovereign power will not be questioned.").

87. Gibbons v. Ogden, 22 U.S. 1, 203 (1824).

88. See generally Slaughter-House Cases, 83 U.S. 36 (1873).

89. Wendy E. Parmet, From Slaughter-House to Lochner: The Rise and Fall of the Constitutionalization of Public Health, 40 AM. J. LEGAL HIST. 476, 482 (1996).

90. Id. at 483 . 
terplay between police power and state sanctioned vaccination until the court in Hazen v. Strong considered citizens' objections to vaccination. In Hazen, the court upheld the power of a local town council to pay for the vaccination of persons exposed to smallpox even though there were no actual cases of smallpox in the community. ${ }^{91}$

Laws mandating immunization first appeared in the early nineteenth century, and the first was promulgated in the Commonwealth of Massachusetts. ${ }^{92}$ In 1827 , Boston was the first city to require the vaccination of public school students. ${ }^{93}$ The policy was later enacted throughout all of Massachusetts. ${ }^{94}$ In an effort to maximize vaccination rates, other states also began implementing mandatory vaccination policies for children attending public school. ${ }^{95}$ During this time period, "[f] ew Fourteenth Amendment cases decided by the Supreme Court actually dealt with state actions designed to protect the public against traditional epidemic diseases." ${ }^{.96}$ Two cases that addressed the issue of state mandated vaccination policies during that time period were Campagnie Fracaise de Navigation a Vapeur v. Louisiana State Board of Health, which upheld a Louisiana Board of Health ban against immigrants at the time in which infectious diseases were prevalent, ${ }^{97}$ and Jacobson v. Massachusetts, which upheld a Massachusetts ordinance requiring a mandatory smallpox regulation. $^{98}$

Jacobson v. Massachusetts is the seminal United States Supreme Court decision affirming the power of the state to compel vaccination. ${ }^{99}$ In Jacobson, a Massachusetts statute gave local boards of public health the power to require vaccination for the residents of their respective towns. ${ }^{100}$ On February 27 , 1902, the Board of Health of Cambridge required all residents of the city to be vaccinated for smallpox. ${ }^{101}$ Jacobson refused to be vaccinated, claiming that the statute abridged his privileges as a citizen, deprived him of liberty without due process of law, and was thereby a violation of his Fourteenth Amendment rights. ${ }^{102}$ The Supreme Court ruled that it is within the police power of a state

91. Hazen v. Strong, 2 Vt. 427 (1830).

92. Hodge, Jr. \& Gostin, supra note 1, at 851. President Thomas Jefferson was the first to recognize the public health value of vaccinations. He was occasionally called the "greatest patron of vaccination in America," inoculating hundreds of his own family members and friends. Id. at $842-43$.

93. Id. at 851 .

94. Id.

95. Id.

96. Parmet, supra note 89 , at 493.

97. See generally Compagne Francaise de Navigation a Vapeaur v. La. State Bd. of Health, 186 U.S. 380 (1902).

98. See generally Jacobson v. Mass. 197 U.S. 11 (1905). See also Parmet, supra note 89, at 493-94.

99. Id. Many states had, however, already required citizens to submit to mandatory vaccinations for a variety of diseases, including smallpox.

100. Id. at 12-13.

101. Id.

102. Id. at 13-14. 
to enact a compulsory vaccination law, and it is for the legislature, not the courts, to determine whether vaccination is, or is not, the best mode for the prevention of smallpox and the protection of the public health. ${ }^{103}$ The Court found that when the Board of Health adopted the regulation, smallpox was prevalent and the disease was spreading. ${ }^{104}$ Because state police powers include regulations created to protect the public health, and the public health was threatened by smallpox, both the Massachusetts statute and the regulation governing the Boards of Health were deemed valid by the Court. ${ }^{105}$

The Court acknowledged the possibility that vaccines might not be an effective means to prevent and control the spread of smallpox; however, it determined that the legislature has the right to pass laws that, according to the common belief of the people, are adapted to prevent the spread of contagious diseases. ${ }^{106}$

In a free country, where the government is by the people, through their chosen representatives, practical legislation admits of no other standard of action, for what the people believe is for the common welfare must be accepted as tending to promote the common welfare, whether it does in fact or not. ${ }^{107}$

The Court could not and did not decide that vaccination would prevent smallpox; however, it took judicial notice of the fact that it was the common belief of the people of the state that it would. ${ }^{108}$ Based on this rationale, the Court held that the statute in question was a public health law enacted through a reasonable and proper exercise of the state's police power. ${ }^{109}$ Furthermore, the Court concluded that a minority of citizens could not defy the decisions of their legislature, when the legislature acted "in good faith for all" if the minority's actions would endanger the welfare of the entire community. ${ }^{110}$

Although the Court ruled that the mandatory vaccination statute fell within the state police powers of Massachusetts, the Court did prescribe limits to such power. Specifically, the Court set forth a reasonableness test for mandatory vaccination statutes that examined the reasonableness of the relationship between the state's vaccination policy and its obligation to protect the public health. ${ }^{111}$ In Jacobson, the vaccination program was deemed reasonable because smallpox was prevalent in Cambridge, and the Board of Health's only

103. Id. at 12 .

104. Id. at 27.

105. Jacobson, 197 U.S. at 28.

106. Id. at 35 .

107. Id.

108. Id.

109. Id.

110. Jacobson, 197 U.S. at 37-38.

111. Id. at 31 . 
motivation in enacting the mandatory policy was to protect the public from that threat. ${ }^{112}$

The Supreme Court also held that courts may strike down legislation designed to protect the public welfare only when it "has no real or substantial relation to [public health, morals, or safety] or is, beyond all question, a plain, palpable invasion of rights secured by the fundamental law...."113 Ironically, the Court found that state police powers have limits that can be encroached upon by the judiciary when the police powers are used in an "arbitrary and oppressive" manner. ${ }^{114}$ However, this limitation notwithstanding, the Jacobson decision firmly established as a matter of constitutional law that states may utilize their police powers to compel reasonable vaccination in the interest of public health.

Subsequently, however, courts have concluded that state mandated vaccinations do not constitute a violation of either the right to constitutional due process or equal protection. ${ }^{115}$ For example, Adams v. Milwaukee held that vaccination regulations treating cows held outside the city differently than those held inside the city did not violate the Fourteenth Amendment, because they had a "proper relation to the purpose to be accomplished." 116 Seubold v. Fort Smith Special School District held that school vaccination requirements did not deprive individuals of liberty and property interests without due process of the law. ${ }^{117}$ Brown v. Stone held that allowing religious exemption to vaccination violates the Equal Protection Clause because it discriminates against those children whose parents are not religiously motivated. ${ }^{118}$

\section{B. Application of Jacobson Today}

The significant medical, social, and economic benefits provided by vaccinations have led all fifty states to promulgate laws mandating that children be vaccinated before they enter school. Despite all of the positive benefits vaccinations confer, however, an anti-vaccination sentiment is spreading throughout the United States due to misinformation, philosophical and religious beliefs, and a general desire to be free from government coercion. As such, the law faces a difficult challenge in determining how to balance public health welfare against a parent's individual right and freedom to raise his or her child as he or

112. Id.

113. Id. at 31 .

114. Id. at 38 .

115. Steve P. Calandrillo, Comment, Vanishing Vaccinations: Why Are so Many Americans Opting Out of Vaccinating Their Children?, 37 U. MICH. J.L. REFORM 353, 358 (2004) ("Subsequent cases have confirmed that compulsory vaccination laws do not violate one's constitutional right to Due Process or Equal Protection, or interfere with the practice of religion under the First Amendment.").

116. Adams v. City of Milwaukee, 228 U.S. 572, 581-82 (1913).

117. Seubold v. Fort Smith Special Sch. Dist., 237 S.W.2d 884, 887 (Ark. 1951).

118. Brown, et al. v. Stone, et al., 378 So. 2d 218, 223 (Miss. 1979). 
she sees fit, especially now that Gardasil has been approved for use and has the potential to save thousands of American lives annually.

The Supreme Court in Jacobson v. Massachusetts ruled that it is within the police power of a state to enact a compulsory vaccination law. ${ }^{119}$ It went on to note that it is for the legislature and not for the courts to determine whether a vaccination is or is not in the best interest of the public health. ${ }^{120}$ To aid the court in the interpretation of legislative intent, the court established a reasonableness test for mandatory vaccination statutes. ${ }^{121}$ The vaccination statute must be reasonable in light of the prevalence of the disease, and the state must not have any motivation other than the protection of the public's health. ${ }^{122}$

Jacobson was decided in 1905, when smallpox was still a global threat. "Smallpox killed an estimated 300 million people worldwide in the twentieth century ...."123 At the time Jacobson was decided, smallpox was a prevalent and increasing threat in communities throughout the nation. Obviously, therefore, the statute to require smallpox vaccination had a substantial relation to the public's health, and thus, was not considered arbitrary or oppressive. The vaccination was to be administered to everyone and for free if an individual could not afford it. The state was looking out for the good of the people by mandating the vaccination. Moreover, because of the smallpox vaccine, "the World Health Organization embarked on a twelve year inoculation blitz," and by 1979, it declared smallpox eradicated. ${ }^{124}$ The smallpox disease was the first disease to be eliminated from the face of the earth. ${ }^{125}$ Now, states must decide whether or not to add Gardasil to the list of vaccinations that females must receive prior to school entry.

In determining the constitutionality of mandating the Gardasil vaccination, it is necessary to examine issues of substantive due process. Substantive due process guarantees that laws will be reasonable and not arbitrary. ${ }^{126}$ For the court to determine whether or not a state can mandate Gardasil, it must employ a rational basis or minimal scrutiny test. The rational basis standard is used whenever the strict scrutiny or intermediate scrutiny tests are not applicable. ${ }^{127}$ Since mandating a vaccination does not deal with a suspect class, an implied fundamental right, or a classification based on gender or legitimacy, strict and intermediate scrutiny do not apply. ${ }^{128}$ Under the rational basis standard, a law

119. Jacobson, 197 U.S. at 11-12.

120. Id.

121. Id. at 31 .

122. Id.

123. Westhead, supra note 1 , at F1.

124. Id.

125. See, e.g., id.

126. BLACK's LAW DictionaRY 223 (2nd Pocket Ed. 2001).

127. 16B AM. JUR. 2D Constitutional Law \$812 (2007).

128. To date, Gardasil has only been proven effective for females. CDC, HPV ANSWERS, supra note 12. If the on-going studies prove that Gardasil is as safe and effective in males, this Note would encourage mandatory vaccination for both men and women. Until then, this Note can only encourage compulsory vaccination for females. 
will be upheld if it is rationally related to a legitimate interest. ${ }^{129}$ Since it is difficult to fail this test, most governmental action examined under this standard is upheld unless it is arbitrary or irrational. ${ }^{130}$ Moreover, under the rational basis analysis, laws are presumed valid, leaving the challenger with the burden of proof. $^{131}$ Given the amount of deference the Court gives to the legislature's decision, this is a difficult test to meet.

In using the Court's rational basis test to determine if it is constitutional to mandate Gardasil vaccination for females entering school, the law is presumed valid. The burden of proof is placed on the challenger (a parent or guardian opposed to the vaccination) to persuade the court that the law is arbitrary or irrational. Prior to the FDA's approval of Gardasil, challengers to the vaccination began citing several reasons why they would oppose it as a mandatory vaccination. Critics of the vaccination question its effectiveness, oppose the number of vaccines students currently receive, believe that a vaccine should not be mandatory for a disease that could be prevented by behavior modification, fear the vaccine will promote sexual activity, and inhibit a parent's right to make choices for his or her child. Despite these claims, Gardasil should be mandated for children entering school based on the following arguments.

\section{An "All or Nothing" Approach is Not the Best Approach to Take When Thousands of Lives May be Saved by the Vaccine in the United States}

Critics of the Gardasil vaccine question its effectiveness. Gardasil's biggest claim is that it has been found to be " 100 percent effective." 132 It is important to note that Gardasil is $100 \%$ effective against four of the many HPV strains. ${ }^{133}$ Moreover, Gardasil protects against two strains (HPV types sixteen and eighteen) that lead to seventy percent of all cervical cancers, " ${ }^{134}$ "[b]ut 70 percent is not the same as eradication." 135 That still leaves thirty percent of cervical cancer cases untouched. As such, even if every woman in the nation were vaccinated, effective HPV treatment and prevention would still require annual Pap tests. ${ }^{136}$

Barbara Loe Fisher, president and co-founder of the National Vaccine Information Center, has voiced doubt as to the propriety of mandatory HPV vaccination in the United States, since "most [American] women receive regular annual Pap tests." 137 Pap tests usually catch HPV "before it develops into can-

129. BLACK's LAW DiCTIONARY 582-83 (2nd Pocket Ed. 2001).

130. 16B AM. JUR. 2D Constitutional Law $\S 813$ (2007).

131. Id.

132. Sprigg, supra note 18 , at A17.

133. Id.

134. Id.

135. Id.

136. Id.

137. Simons, supra note 17. 
cer."138 Moreover, because of Pap test public awareness campaigns, "the instance of cervical cancer fell 74 percent between 1955 and 1992."139 Although Pap tests have "slashed the rates of most cervical cancers in this country, [they] didn't do the same for a cancer called cervical adenocarcinoma." adenocarcinoma can be missed by a Pap test because it occurs high up in the cervix. $^{141}$

Critics claim that Gardasil should not be mandated because it is not $100 \%$ effective against all strains that lead to cervical cancer; however, this Note contends that, even if $100 \%$ prevention is not possible, mandated vaccination is still the most reasonable approach to take. Using an all or nothing approach to decide whether or not to mandate the vaccine is illogical because such an approach fails to consider that Gardasil is $100 \%$ effective against two of the main strains of HPV that lead to cervical cancer (HPV types sixteen and eighteen). Although Gardasil does not have complete effectiveness against all types of HPV, it can still save thousands of lives each year. It seems logical to suggest however, that savings thousands of lives a year is far better than not saving any lives at all.

\section{Since Safety Concerns and Myths Have Been Addressed, the Number of Vaccines Children Currently Receive Should Not Detract From the Fact That Gardasil Could Save Thousands of Lives}

Another common complaint raised by those who oppose mandatory Gardasil vaccination is that children are already required by state laws to receive a large number of vaccinations. According to Fisher:

In the 1980 s, U.S. children got 23 doses of seven vaccines by age six. Today, they get 48 doses for 14 vaccines in the same period. 'And during the time that vaccines doses have doubled,' she says, 'there's been an increase in the number of children with autism, attention deficit and hyperactive disorder, learning disabilities, asthma, and diabetes, in which vaccines could be a contributing factor. ${ }^{142}$

Professor Neal A. Halsey of the Johns Hopkins University Institute for Vaccine Safety suggests that many of these claims have no merit. ${ }^{143}$ Professor Halsey stated,

138. Id.

139. Id.

140. Marissa Conrad, The Cancer a Pap Could Miss, Glamour, Dec. 2006, at 142.

141. Id.

142. Simons, supra note 17. See also Hodge, Jr. \& Gostin, supra note 1, at 887.

143. Hodge, Jr. \& Gostin, supra note 1 , at 887 . 
The increasing incidence of diabetes, autism, and other medical conditions for which no specific etiology has been identified parallels the increase in many other factors such as the use of wireless communications, computers, and fast food restaurants. One could easily hypothesize that these factors or many other changes in our lifestyles contributed to the increases in these diseases, but there is no scientific evidence to support these ideas. $^{144}$

Despite critics' concerns, Emory's Vaccine Center states that all recommended vaccines are extraordinarily safe. ${ }^{145}$ Side effects are typically limited to a low grade fever or pain and tenderness in the area where the shot was given. ${ }^{146}$

Gardasil's known side effects include pain, itching, fever, nausea, dizziness, and redness at the injection site. ${ }^{147}$ Additionally, positive "post-licensure safety data" for the first eleven months of the United States' experience with Gardasil was recently released. ${ }^{148}$ During a June 2007 meeting of the CDC's Advisory Committee on Immunization Practices, Dr. John Iskander presented data that confirmed serious adverse events associated with Gardasil are rare. ${ }^{149}$ Dr. Iskander noted that "the serious adverse event reporting rate is [only] 1.8 per 100,000 doses." 150 For those injured due to immunizations, Congress passed the National Vaccine Injury Compensation Program in 1986, which provides a no-fault compensation plan with damages for pain and suffering capped at $\$ 250,000 .{ }^{151}$ Gardasil has been covered under this Program since February 1, 2007, and no claims involving the Gardasil vaccine have been filed as of June $7,2007 .^{152}$

Moreover, the FDA is currently considering whether to approve Pentacel, "a five-in-one vaccine that could reduce the number of jabs children receive.",153 Pentacel is designed to replace the shots for polio, diphtheria, tetanus, pertussis, and Hib. ${ }^{154}$ Thus, the number of vaccinations that children are required to

144. Id.

145. Vaccines 101: Vaccine Myths, EMORY VACCINE CENTER, 2004, http://www.vaccines .emory.edu/vaccines/myths/shtml (last visited Mar. 20, 2008).

146. Id.

147. GARDASIL PAMPHLET, supra note 10.

148. Heidi Splete, Largest Study to Date Supports Gardasil's Safety in First Year of Use, PEDIATRIC News, July 1,2007, at 15, 15. As of the end of March 2007, more than five million doses of Gardasil have been distributed in the United States. Id.

149. Id.

150. Id.

151. The Public Health Service, National Vaccine Injury Compensation Program: Compensation, 42 U.S.C. § 300aa-15 (1997).

152. Splete, supra note 148 , at 15 .

153. FDA Advisers Back 5-in-1 Childhood Vaccine: If Approved, Concoction Could Eliminate 7 of the Jabs Kids Receive, AssocIATED PRESS, Jan. 25, 2007, available at http:// www.msnbc.msn.com/id/16813053/wid/11915773?GT1=8921 (last visited Mar. 20, 2008).

154. Id. (stating that the vaccine first appeared in Canada in 1997 and is now available in 
receive will likely be reduced in the near future. Consequently, because vaccinations have been proven safe and Gardasil's side effects are mild, the Gardasil vaccine should be given to girls prior to entering school.

\section{Regardless of the Fact That HPV Could be Reduced Through Behavior Modification, Gardasil Should be Viewed in the Same Light as the Vaccine for Hepatitis $B$}

Other critics of Gardasil feel that a compulsory vaccination is not necessary for a disease such as HPV that is not transmitted through casual contact. ${ }^{155}$ "Since the bringing together of large numbers of children clearly facilitated the spread of smallpox, and since vaccination provided a relatively safe preventive, it was natural that compulsory school attendance laws should lead to a movement for compulsory vaccination." ing with the transmission of HPV. Cervical cancer and genital warts are not contagious diseases in the same manner as mumps, measles, and chicken pox, which can be spread in classrooms. ${ }^{157}$ The strains of HPV that cause cervical cancer and genital warts are transmitted "through sexual contact," which are activities children are not (or should not be) engaging in at school. ${ }^{158}$ Although, with the recent discovery of HPV under young men's fingernails, scientists have admitted they have more to learn about how HPV is really transmitted.

The concern for how the disease is transmitted did not prevent states from including hepatitis B on the list of required immunizations for adolescents attending school. ${ }^{159}$ Every state except Montana requires that children entering either day care or school be immunized against hepatitis B. ${ }^{160}$ Moreover, the $C D C$ recommends all infants receive the hepatitis $B$ vaccine even though hepatitis B is an adult disease that is not highly contagious, deadly (for most that contract it), or present at epidemic levels in the United States (except among high-risk groups). ${ }^{161}$

Although the virus for hepatitis B can be found in saliva, it is not commonly transmitted by casual contact. ${ }^{162}$ Hepatitis B is primarily transmitted "through infected body fluids." ${ }^{.163}$ However, hepatitis B, is not a deadly disease for most people. ${ }^{164}$

eight other countries).

155. Sprigg, supra note 18 , at A17.

156. Hodge, Jr. \& Gostin, supra note 1, at 850 (quoting John Duffy, School Vaccination:

The Precursor to School Medical Inspection, 33 J. HIST. MED. 344, 345 (1978)).

157. Major Breakthrough, supra note 13, at A8.

158. Sprigg, supra note 18, at A17.

159. Gian Aliprendi, Immunization Requirements by State, SABIN VACCINE INST., Mar. 20, 2007, available at $\mathrm{http}: / / \mathrm{www}$. sabin.org/files/PDF/immunization_schedule_2007.pdf.

160. Id.

161. Nat'l Vaccine Info. Ctr., Hepatitis B Vaccine: The Untold Story, http:// www.nvic.org/Diseases/hepbnlr.htm (last visited Mar. 20, 2008).

162. Id.

163. Id.

164. Id. 
[I]n cases of acute hepatitis B 'most patients do not require hospital care' and ' 95 percent of patients have a favorable course and recover completely' with the casefatality ratio being 'very low (approximately 0.1 percent).'

Those who recover completely from hepatitis $\mathrm{B}$ infection acquire life-long immunity. Of those who do not recover completely, fewer than 5 percent become chronic carriers of the virus with just one quarter of these in danger of developing life threatening liver disease later in life.. .$^{165}$

Despite these statistics, every state but Montana requires immunization for hepatitis B prior to entering school. ${ }^{166}$ According to Staci Geller, head of Illinois' Cervical Cancer Elimination Task Force:

'[It] needs to be explained that in many ways [Gardasil] is a vaccine like other vaccines that we give to healthy children. You want to protect against cervical cancer and not get caught up in the mode of transmission ....' 'If we told people you get HPV by coughing, they'd be in the doctor's office in a minute. But nobody wants to think about their daughter having sex. ${ }^{167}$

Since hepatitis B and HPV are both transmitted through non-casual contact, and cervical cancer results in more harm as it kills nearly 4000 American women annually, the Gardasil vaccine should be mandated throughout the country just like the hepatitis $B$ vaccine.

165. Id.

166. Aliprendi, supra note 159. Many question whether mandatory hepatitis B vaccinations are paving the way for forced vaccination with the Acquired Immune Deficiency Syndrome ("AIDS") vaccine. Hepatitis B is not transmitted by casual contact like smallpox or polio; rather, it is transmitted by high risk behavior such as intravenous drug use and sexual promiscuity. As such, it is the first high risk transmission disease for which mandatory vaccination has been required for all children. With identical transmission routes as HIV, there are strong indications that forced vaccination of infants and children with hepatitis B is just a trial run for forced vaccination with an AIDS vaccine when it eventually reaches the market. Illinois State Representative Mary Flowers is sponsoring a bill that would require HIV tests during each of the three school physicals currently required by state law. See Laura Camper, Bill Proposes HIV Tests for Students, THe STATE JouRNAL-REGISTER, Jan. 21, 2007, at A13.

167. Judy Peres \& Bruce Japsen, States Craft HPV Vaccine Bills, ChiCAGo TriBune, Feb. 11,2007 , at $\mathrm{C} 3$. 


\section{Mandating Gardasil Will Not Encourage Children to Engage in Sexual Activity}

The hottest debate with regard to mandating Gardasil primarily centers on conservative organizations such as the Family Research Council and Focus on the Family, which oppose anything they believe promotes or condones premarital sex. ${ }^{168}$ Micah Clark, director of the American Family Association of Indiana, believes that mandating Gardasil will say to girls: "Hey, you can engage in sexual activity and not be at risk for this disease ...."169 However, no research exists that suggests giving a young girl a vaccine against an STD would encourage her to become sexually active. ${ }^{170}$ "Seat belts do not cause reckless driving, tetanus shots do not cause children to seek out rusty nails . . . support and approval of HPV vaccination is not synonymous with support and approval of promiscuity. Rather, it is a cry to rally together to eradicate cervical cancer worldwide."171 Moreover, the University of North Carolina at Chapel Hill School of Public Health conducted a study that effectively negates Micah Clark's belief that mandating Gardasil would give young women a false sense of security.

The study found that girls who were vaccinated with Gardasil were not likely to engage in sex more often than those who were not. ${ }^{172}$ Noel T. Brewer, assistant professor of health behavior and health education at the University of North Carolina at Chapel Hill and author of the study, said, "One of the main arguments against vaccinating young women for HPV is that they will somehow compensate for the vaccine's protective nature by having more sex .... Our findings say otherwise."173 Additionally, the vaccine will not leave girls with a message that they are invincible against HPV or cervical cancer because most girls will not even know what vaccine they are receiving at the doctor's office. Indeed, the majority of girls receive multiple required shots for school and few ask questions. However, if a girl does inquire about what vaccination she is receiving, the doctor should inform the girl what the vaccine prevents and stress that it is not $100 \%$ effective in preventing the disease. Indiana Senator Connie Lawson said, "Parents and pediatricians need to explain that it's a vaccine against cancer .... It's not about promiscuity. If I am a female and I re-

168. Simons, supra note 17.

169. Staci Hupp, Senators: Vaccinate Girls Against Cancer Virus, THE INDIANAPOLIS STAR, Jan. 18, 2007, at A8 [hereinafter Hupp, Senators: Vaccinate] (quotation in original).

170. Fighting Cancer, supra note 44, at B10.

171. Carolyn Susman, HPV Vaccine May Also be Given to Boys, Sun Herald, Aug. 3 , 2006 , at B1 (quotation in original).

172. Press Release, The University of North Carolina-Chapel Hill, Human Papillomavirus Vaccine Does Not Lead Adolescent Girls to Have More Sex, Most Parents Agree (July 5, 2007) (on file with the Author).

173. Id. (quotation in original). 
main abstinent until I get married, there's no guarantee that the man that I marry will not have HPV.",174

\section{Mandating Gardasil is in the Child's Best Interest}

Pro-family groups firmly believe that parents alone "should decide what is best for their children." 175 Those groups believe that "just because something is good for you the government should [not] force you to do it . ..."176 As such, an argument could be made that parents have a substantive due process right to privacy and family autonomy with regard to child rearing, which would require a strict scrutiny analysis when deciding whether to mandate Gardasil. However, most courts do not generally follow strict scrutiny review in such instances citing that a parent's right to make decisions and control his or her child is not without limitations, especially with regard to the education and the health of a child. ${ }^{177}$ "[T] rect the upbringing and education of one's children is among those fundamental rights whose infringement merits heightened scrutiny."178 Yet, the First and Tenth Circuit Courts of Appeal have held that "the parental right to direct the upbringing and education of children ... does not include a right to exempt one's child from public school requirements" such as mandatory immunizations. $^{179}$

Thus, the government should mandate Gardasil vaccinations to prevent many parents from opting out of the vaccine due to inaccurate information on the safety of vaccines, or due to fears that it will promote sexual activity, which studies disprove. Parents, in their efforts to protect their child from one of these harms, would actually hurt their child by denying her access to this life-saving

174. Hupp, Senators: Vaccinate, supra note 169 , at A8 (quotation in original).

175. Sprigg, supra note 18 , at A17.

176. Id.

177. See Fields v. Palmdale Sch. Dist., 427 F.3d 1197, 1208-11 (9th Cir. 2005), opinion amended on denial of rehearing, 447 F.3d 1187 (9th Cir. 2006) (The parents of elementary school students brought an action against the school district when they learned that the school conducted surveys with their children about sexual topics, to better understand the psychological barriers to learning. The parents claimed a violation of their right to privacy and right to control the upbringing of their children. The U.S. Court of Appeals held that parents have no fundamental right to control the upbringing of their children by introducing them to matters of sex in accordance with their personal and religious beliefs. The 9th Circuit used a rational basis test claiming that the survey did not violate a fundamental right); Leebaert v. Harrington, 332 F.3d 134, 135-39 (2d Cir. 2003) (The parents of a student brought an action against the school board of education claiming it had violated their son's rights by refusing to excuse him from a mandatory health education course and subsequently failing him. The Court of Appeals held the parents' claim was subject to a rational basis review, rather than strict scrutiny because there is no fundamental right that includes the right to tell public schools what to teach or not to teach.); Brown v. Hot, Sexy \& Safer Productions, Inc., 68 F.3d 525, 533 (1st Cir. 1995) (holding that a parental challenge to a public school's AIDS awareness and sex education program was not rooted in a constitutionally protected right).

178. Brown, 68 F.3d at 533.

179. Leebaert, 332 F.3d at 140. 
vaccination. The state would be looking out for the children's health by mandating Gardasil, which meets the required rational basis review.

\section{States Should Mandate Gardasil to Ensure that the Vaccine's Cost is Covered so that the Highest Number of Females Have Access to the Vaccine}

Whether or not a state "recommends" or "requires" a vaccine is becoming an important distinction in some states when considering the cost of the vaccine. Recently, the State of Indiana announced a plan to charge many parents for vaccines that are recommended but not required. ${ }^{180}$ In support of this contention, Indiana officials cite the fact that the availability of government funding for vaccines has not kept pace with the costs of vaccine administration. ${ }^{181}$ Under Indiana's proposed plan, vaccines for diphtheria, tetanus, acellular pertussis, measles, mumps, rubella, polio, hepatitis $\mathrm{B}$, and chicken pox will remain free; however, the vaccines for influenza, hepatitis A, meningitis, rotavirus, tetanus diphtheria, and tetanus diphtheria acellular petussis will be subject to fees. ${ }^{182}$ If Indiana merely recommends the Gardasil vaccine, fewer females will receive the vaccine because its costs will not be covered under the new plan unless they have insurance or can qualify for the vaccine under the Vaccines for Children Program. Therefore, in order to ensure that all females have access to Gardasil, states should mandate the vaccination.

\section{Vaccination Programs Save Money in the Long-Run}

Large scale vaccination programs have been proven to save money overall, and "mass vaccinations in America have yielded tremendous financial savings." 183 Various methods such as benefit-risk, benefit-cost, and costeffectiveness analysis have been used to determine that vaccine-preventable diseases cost sixteen times more in medical-related costs than do the vaccines that prevent those diseases. ${ }^{184}$ That statistic is staggering as "American adults contracting vaccine-preventable diseases still result in $\$ 10$ billion worth of unnecessary health care costs and more than 30,000 otherwise avoidable U.S. deaths each year." 185 Gardasil costs a total of $\$ 360$ for the three necessary shots in addition to the doctor's administration fee, which many might consider very

180. See generally Staci Hupp, Under Vaccine Plan, Parents Pay; Health Officials Worry Kids Won't Get Certain Shots, THE InDIANAPOLIS STAR, Jan. 14, 2007, at B1.

181. Id. Federal payments to the state for vaccines total about $\$ 10$ million annually; however, costs to administer the shots are estimated at $\$ 19$ million a year. This lag in funding can be attributed to the fact that the number of vaccines have more than doubled in the past two decades. According to the CDC, "[i]n 1985, it cost about $\$ 45$ to fully vaccinate a child." In 2006 , it cost approximately $\$ 837$ to fully vaccinate a child. $I d$.

182. Id.

183. Calandrillo, supra note 115 , at 379.

184. Id. at 379-80.

185. Id. 
expensive. ${ }^{186}$ However, a number of major health insurance companies have already agreed to cover the cost of the HPV vaccination in their policies. ${ }^{187}$ As such, "[i]nsurance plans covering 60 percent of Americans who receive healthcare benefits already pay for at least part of Gardasil's [\$360] cost ...."188 Furthermore, in 2006, the CDC voted to add Gardasil to its list of vaccines provided by the federal Vaccines for Children Program. ${ }^{189}$ This means that Medicaid-eligible, uninsured or underinsured, and Native American girls ages nine to eighteen can now receive Gardasil vaccinations free of charge. ${ }^{190}$

\section{Mandatory Vaccination Programs Ensure Universal Coverage Thereby} Creating the Most Effective Way to Prevent Diseases Such as HPV and Cervical Cancer

The courts have traditionally aligned themselves with the views of state legislators, school board officials, and public health experts who supported the need for vaccination to preserve communal well-being. "[M]andatory vaccination programs for public school students help to assure nearly universal coverage." 191 Dr. Walter Orenstein, Director of the National Immunization Program, stated "school laws establish a system for immunization, a system that works year in and year out, regardless of political interest, media coverage, changing budget situations, and the absence of vaccine-preventable disease outbreaks to spur interest." 192 In 1963, twenty states throughout the country required immunization against certain diseases for school entrance. ${ }^{193}$ By 1970 , the number of states requiring immunization increased to twenty-nine. ${ }^{194}$ A study published in 1969 demonstrated that states with actively-enforced laws covering the total school population correlated with lower rates of measles. ${ }^{195}$ The 1969 study attracted the attention of many states, and by 1980, all fifty states had enacted school immunization laws. ${ }^{196}$

186. CDC, HPV ANSWERS, supra note 12 .

187. Sabine Vollmer, Few Pediatricians Have First Cancer Vaccine, THE NEws \& OBSERVER (Releigh, N.C.), Oct. 7, 2006 (on file with the author).

188. Id.

189. Doan, supra note 66, at B3.

190. CTr's for Disease Control \& Prevention U.S. Dep'T of Health \& Human SERVICES, VFC:FOR PARENTS (2006), http://www.cdc.gov/nip/vfc/Parent/parent_home.htm (last visited Mar. 20, 2008).

191. Zoltan, supra note 2, at 736.

192. Daniel A. Salmon, Mandatory Immunization Laws and the Role of Medical, Religious, and Philosophical Exemptions 1 (Oct. 2003) (unpublished Commentary, on file with the author).

193. Id.

194. Id.

195. Id.

196. Id. 
Requirements that students receive a vaccine prior to enrollment in school "have proven effective in preventing infectious diseases and help to decrease racial and ethnic disparities in vaccine utilization." ${ }^{197}$ Moreover,

\begin{abstract}
Vaccines have dramatically reduced morbidity and mortality rates of some of the worst diseases in history by preventing them on the front end. The benefits have been remarkable: millions of deaths have been prevented, millions more lives markedly improved, and billions of dollars of societal resources have been saved for use in countless other valuable endeavors. ${ }^{198}$
\end{abstract}

Today, vaccines protect against over twenty deadly diseases including smallpox, measles, mumps, rubella, diphtheria, tetanus, pertussis, polio, hepatitis A and $\mathrm{B}$, some forms of influenza, pneumoccocal disease, Hib, and varicella. ${ }^{199}$

\title{
9. Many States Have Begun Measures to Mandate Gardasil
}

Over forty states and the District of Columbia have introduced legislation that would allocate funding to educate the public about Gardasil, with at least twenty states specifically seeking to mandate the vaccine for female students. ${ }^{200}$ Since January of 2007, at least twenty-four states, as well as the District of Columbia, have introduced legislation that would specifically mandate the Gardasil vaccination for girls entering public school. ${ }^{201}$ States have, however, faced challenges to the passage of statutes intended to make Gardasil vaccination mandatory. For example, in Michigan and Ohio, legislators attempted to pass legislation mandating use of the vaccine, but failed. ${ }^{202}$ In February of 2007, Texas almost became the first state to mandate Gardasil for girls attending public school. $^{203}$ Texas Governor, Rick Perry, issued an executive order to bypass the Legislature to ensure the mandate would be in effect by the fall of $2008 .^{204}$ Governor Perry's executive order would have allowed parents to opt out of the

197. Simons, supra note 17.

198. Calandrillo, supra note 115 , at 369 .

199. Id. at $369-81$

200. Clarence Page, Wise, but Unnecessary HPV Laws, CHICAGo TRIB., Feb. 11, 2007, at C7. See also NAT'L Conf. OF State Legislatures, HPV VACCINE, www.ncsl.org/ programs/health/HPVvaccine.htm\#hpvlegis (last visited Mar. 20, 2008).

201. NAT'L CONF. OF STATE Legislatures, supra note 200. The following states attempted to mandate Gardasil vaccination in 2007: California, Colorado, Florida, Georgia, Illinois, Kansas, Kentucky, Maryland, Massachusetts, Michigan, Minnesota, Mississippi, Missouri, New Jersey, New Mexico, New York, Ohio, Oklahoma, South Carolina, Texas, Vermont, Virginia, and West Virginia. Id.

202. Id.

203. Required STD Shots Worry Some Parents, Associated Press, FeB. 5, 2007, http:// www.msnbc.msn.com/id/16975112/wid/11915773?GT1=9033 (also on file with the author).

204. Id. 
vaccination due to either religious or philosophical reasons; however, state legislators passed a bill in April of 2007 blocking Governor Perry's executive order. ${ }^{205}$ Because Governor Perry said that he would not veto the bill, Virginia has now officially become the first state to mandate the Gardasil vaccine. ${ }^{206}$

Under the Virgina Statute, sixth-grade girls must be vaccinated with Gardasil beginning in 2009 unless parents choose to opt their daughters out of the program. ${ }^{207}$ Moreover, as a result of the Virginia mandate, Planned Parenthood of Southeastern Virginia has added Gardasil to the services available at its clinics. ${ }^{208}$ The City Council of the District of Columbia has also passed a bill mandating Gardasil for females before the age of thirteen; however, it is awaiting Congressional approval. ${ }^{209}$

Many states have also enacted legislation that will provide the vaccine to females at little or no cost. The New Hampshire Health Department has agreed to provide Gardasil at no cost to females under the age of eighteen. ${ }^{210}$ In less than one year, the New Hampshire Health Department has distributed over 14,000 doses. ${ }^{211}$ South Dakota has announced a plan similar to New Hampshire's. The South Dakota Department of Health now offers Gardasil to young women between the ages of eleven and eighteen, free of charge. ${ }^{212}$ In less than one year, the South Dakota Department of Health has dispensed over 20,000 doses of the vaccine. ${ }^{213}$

When claims are reviewed under the rational basis analysis, it would be constitutional for states to mandate the Gardasil vaccination for girls entering the sixth grade. Although the vaccine will not completely prevent all cases of cervical cancer and genital warts, it will drastically reduce the 3700 deaths that result in the United States annually from cervical cancer. ${ }^{214}$ The fact that HPV is not transmitted through casual contact like many of the diseases that have warranted mandatory vaccination is not reason enough to continue allowing thousands of women to die when there is a vaccine that could substantially reduce the mortality rate. By requiring the vaccine for HPV, the government is not condoning or encouraging females to engage in sexually promiscuous activity. In actuality, the government is merely recommending that the vaccine be administered to females at an age when they are impressionable and will discuss the vaccine with their doctor and parents. Females will hopefully realize

205. Id. See also Heather Burcham, Cervical Cancer Victim Fought for HPV Vaccine; Urged Legislators in Texas to Save Young Girls' Lives, CHICAGO SUN TIMES, July 26, 2007, at 57.

206. Id. See also Elizabeth Simpson, Planned Parenthood Offering HPV Vaccines, VIRGINIA PILOT \& LEDGER-STAR, July 10, 2007, at A12.

207. Simpson, supra note 206, at A12.

208. Burcham, supra note 205, at 57.

209. NATIONAL CONFERENCE OF STATE LEGISLATURES, supra note 200.

210. Id.

211. Id.

212. See Id.

213. Id.

214. Major Breakthrough, supra note 13, A8. 
the dangers that can result from sexual promiscuity and be more cautious if they eventually decide to engage in sexual behavior. Moreover, if states require every eleven year-old girl to receive the Gardasil vaccine prior to entering school, the mandate can not be considered arbitrary. The states are taking steps for the greater good of the community: to protect the health of every female against cervical cancer, a life-threatening illness that thousands of Americans lose their lives to each year.

\section{IT IS CONSTITUTIONAL FOR THE STATE TO DENY PARENTS' RELIGIOUS AND PHILOSOPHICAL EXEMPTIONS TO THE GARDASIL VACCINE}

\section{A. Cases Discussing Exemptions to Vaccinations}

Rather than having each state's health department require immunization during an emergency, state legislatures have adopted mandatory immunization requirements for children entering school or day care facilities to prevent the spread of diseases. ${ }^{215}$ All fifty states, the District of Columbia, and Puerto Rico have implemented mandatory vaccination laws that cover children "from kindergarten through 12th grade" in public and private schools, as well as children enrolling in day care. ${ }^{216}$ Although "the CDC publishes a schedule of immunizations based on the recommendations of the Advisory Committee on Immunization Practices, the American Academy of Pediatrics' Committee on Infectious Diseases, and the American Academy of Family Physicians," each state independently determines the vaccinations required for school entry in that state, as well as if it will permit medical, philosophical, or religious exemptions for the vaccinations. $^{217}$

\section{Medical Exemptions}

All fifty states allow medical exemptions to vaccinations. ${ }^{218}$ Children who are immuno-compromised, suffer from cancer, or who are allergic to the vaccines typically qualify for a medical exemption. ${ }^{219}$ Proof of medical exemption must take the form of a signed statement by a medical doctor stating that the administration of one or more vaccines would be detrimental to the health of the child. ${ }^{220}$ The power of clinicians to circumvent mandatory vaccination

215. Hodge, Jr. \& Gostin, supra note 1 , at 868 .

216. Alan R. Hinman et al., Tools to Prevent Infectious Disease: Childhood Immunization: Laws That Work, 30 J.L. MED. \& ETHICS 122, 124 (2002).

217. Hodge, Jr. \& Gostin, supra note 1 , at 868.

218. Hinman et al., supra note 216 , at 124.

219. Id.

220. NAT'L VACCINE INFO. CTR, LEGAL EXEMPTIONS TO VACCINATION (2006), http://www. nvic.org/state-site/legal-exemptions.htm [hereinafter NATIONAL VACCINE INFORMATION CENTER, LEGAL EXEMPTIONS] (last visited Mar. 20, 2008). 
requirements is not, however, unlimited. For example, most states do not allow chiropractic doctors to write medical exemptions to vaccination. ${ }^{221}$

\section{Philosophical Exemptions}

Philosophical exemptions refer to other non-religious beliefs held by the parents who do not believe that their child should be immunized. Twenty states allow exemptions to vaccination based on philosophical, personal, or conscientiously-held beliefs. ${ }^{222}$ In order to employ the philosophical or personal belief exemption in many of these states, "individuals must object to all vaccinations, not just one particular vaccine." ${ }^{223}$ However, federal health officials and medical organizations are urging state legislators to revoke this type of exemption to vaccinations because many parents are merely using it as a convenient way to avoid the necessity of conforming to the state's vaccination mandates and recommended immunization schedule. ${ }^{224}$

\section{Religious Exemptions}

The religious exemption is granted based on the First Amendment to the Constitution, which grants the right to freely exercise one's religion. Because citizens are protected under the First Amendment, it has been said that a state must have a "compelling state interest" before this right can be taken away. ${ }^{225}$ In Jacobson v. Massachusetts, discouraging the spread of communicable diseases was proven to be a compelling state interest. ${ }^{226}$ However, the court in Prince v. Massachusetts held that the freedom to act according to one's own religious beliefs is subject to reasonable regulation when society's welfare is threatened. ${ }^{227}$

Today, forty-eight states provide for religious exemptions to vaccination requirements, with Mississippi and West Virginia as the only states that do not. ${ }^{228}$ The National vaccine Information Center states that:

The religious exemption is intended for people who hold a sincere religious belief opposing vaccination to the ex-

221. Id.

222. NAT'L NETWORK FOR IMMUNIZATION INFO., IMMUNIZATION POLICY: EXEMPTIONS FROM IMMUNIZATION LAWS (2005), http://www.immunizationinfo.org/immunization_policy_detail. cfv?id=44 (noting that the following twenty states have philosophical exemptions: Arizona, Arkansas, California, Colorado, Idaho, Louisiana, Maine, Michigan, Minnesota, Missouri, Nebraska, New Mexico, North Dakota, Ohio, Oklahoma, Texas, Utah, Vermont, Washington, and Wisconsin) (last visited Mar. 20, 2008).

223. NATIONAL VACCINE INFORMATION CENTER, LEGAL EXEMPTIONS, supra note 220.

224. Id.

225. See Sherbert v. Verner, 374 U.S. 398, 403 (1963).

226. Jacobson, 197 U.S. at 11, 11 (1905).

227. Prince v. Mass., 321 U.S. 158, 166-68 (1905).

228. Calandrillo, supra note 115 , at 413 (citation omitted). 
tent that if the state forced vaccination, it would be an infringement on their right to exercise their religious beliefs. Some state laws define religious exemptions broadly to include personal religious beliefs, similar to personal philosophical beliefs. Other states require an individual who claims a religious exemption to be a member of The First Church of Christ, Scientist (Christian Science) or another bonafide religion whose written tenets include prohibition of invasive medical procedures such as vaccination. (This kind of language has been ruled unconstitutional when it has been challenged in state Supreme Courts.) Some laws require a signed affidavit from the pastor or spiritual advisor of the parent exercising religious exemption that affirms the parents' sincere religious belief about vaccination, while others allow the parent to sign a notarized waiver. ${ }^{229}$

Although forty-eight states currently permit a religious exemption to vaccination based on the First Amendment, states may prohibit or regulate conduct in general. $^{230}$ This is true even if the prohibition or regulation happens to interfere with a person's religious practices. ${ }^{231}$

The Free Exercise Clause cannot be used to challenge a law of general applicability unless it can be shown that the law was motivated by a desire to interfere with religion. ${ }^{232}$ Despite the fact that many states offer the religious exemption, "the U.S. Supreme Court has never ruled on the constitutionality of religious exemptions from vaccination requirements."233 Pertinent case law suggests that "mandatory immunization against dangerous diseases does not violate the First Amendment right to free exercise of religion," as long as there is no conflict between the two. ${ }^{234}$

In Employment Division v. Smith, the Court stated, "[w]e have never held that an individual's religious beliefs excuse him from compliance with an otherwise valid law prohibiting conduct that the state is free to regulate. ${ }^{, 235}$ In the 1990 s, the Court retreated from its strict scrutiny standard and held that, as long

229. NATIONAL VACCINE INFORMATION CENTER, LEGAL EXEMPTIONS, supra note 220.

230. Id.

231. Id.

232. Emp. Div. v. Smith, 494 U.S. 872 (1990). In Smith, a prohibition against the use of peyote was challenged by a person whose religious beliefs require use of peyote during religious ceremony. Despite the challenger's religious beliefs, the court was not required to provide a religious exemption for him. Id. The Supreme Court held that no religious exemption was required because of the religiously-neutral nature, even though people objected because the regulation interfered with conduct inspired by sincerely held religious beliefs. $I d$.

233. Salmon, supra note 192, at 2.

234. Id.

235. Smith, 494 U.S. at 895 . 
as the law is religion-neutral and generally applicable, it does not interfere with the right to free exercise of religion. ${ }^{236}$ The Court did note two exceptions to this rule of minimum scrutiny. One exception to the rule of minimum scrutiny is when there is a violation of both the Free Exercise Clause and a second constitutional right such as freedom of speech or a parent's right to direct the education of his or her child. ${ }^{237}$ This exception is known as the hybrid-rights exception.

In Prince v. Massachusetts, the Court held that the First Amendment's Free Exercise Clause does not allow for the right to expose the community or one's children to harm from disease. ${ }^{238}$ The Court held:

The right to practice religion freely does not include liberty to expose the community or the child to communicable disease or the latter to ill health or death.

... Parents may be free to become martyrs themselves. But it does not follow they are free, in identical circumstances, to make martyrs of their children before they have reached the age of full and legal discretion when they can make that choice for themselves. ${ }^{239}$

The court in Wright v. DeWitt School District followed that rationale when it ruled that a compulsory vaccination law with no religious exemption is constitutional because the right to free exercise of religion is subject to reasonable regulation for the good of the community. ${ }^{240}$ Several state courts have applied this reasoning in ruling that mandatory vaccination of school children does not interfere with the right to religious freedom. In Cude v. Arkansas, the Arkansas Supreme Court noted, "In cases too numerous to mention, it has been held, in effect, that a person's right to exhibit religious freedom ceases where it overlaps and transgresses the rights of others.",241

\section{B. It is Constitutional for the State to Deny Parents Non-Medical Exemptions to the Gardasil Vaccine}

The late Nineteenth Century was the last period in American history when societal integrity was routinely threatened by "ravaging epidemics of infectious disease." 242 As such, many individuals today have never witnessed the debili-

236. Id. at 886 .

237. Id. at 881 .

238. Prince, 321 U.S. at $166-70$.

239. Id.

240. Wright v. DeWitt Sch. Dist., 385 S.W.2d 644, 648 (Ark. 1965).

241. Cude v. Arkansas, 377 S.W.2d 816, 817 (Ark. 1964).

242. Parmet, supra note 89 , at 477. 
tating diseases that vaccines protect against, a situation which has allowed an attitude of complacency toward immunization requirements to build. Dr. Edward P. Rothstein, a Pennsylvania pediatrician who helps the American Academy of Pediatrics make immunization recommendations, recalled:

I remember how the fear of polio changed our lives -not going to the swimming pool in the summer, not going to the movies, not getting involved with crowds .... I remember pictures of wards full of iron lungs, hundreds in a room, with kids who couldn't breathe in them. It affected daily life more than AIDS does today. ${ }^{243}$

Clearly, Americans are no longer accustomed to the terrors, both real and imagined of incurable epidemic diseases.

In addition to not witnessing the effects of the life-threatening diseases, the anti-vaccination sentiment is quickly growing in the United States due to the disputed link between immunizations and autism, which is in large part due to sensational media stories. ${ }^{244}$ As such, increasing numbers of parents are refusing immunizations for their children and seeking legally-sanctioned exemptions instead. ${ }^{245}$ State legislatures and health departments now face a difficult challenge in that they must design and implement legislation and policies that both respect individual rights and freedoms while at the same time safeguarding the public welfare. ${ }^{246}$

Exemptions from mandatory vaccinations pose a serious threat to the public health. Studies show that unvaccinated children may be twenty-two times more likely to suffer from measles than their vaccinated peers. ${ }^{247}$ By causing a decline in the overall immunization levels in the United States, "unvaccinated children increase the risk of disease exposure and transmission" in a community. ${ }^{248}$ Since high immunization levels indirectly protect the community as a whole through "herd immunity," a decline in vaccinated children can lead to disease resurgence. ${ }^{249}$

Not only do exemptions threaten public health, but they also cause some parents to opt out of the vaccinations merely as a convenience. According to Dr. Walter A. Orenstein, director of the National Immunization Program at the CDC, "[a]cross the country about 1 percent of all children are exempt from

243. Donald G. McNeil, Jr., When Parents Say No to Child Vaccinations, N.Y. TimeS, Nov. 30, 2002, at A2.

244. Calandrillo, supra note 115 , at 421 .

245. Id.

246. Id. at 429 .

247. Daniel R. Feiken et al., Individual and Community Risks of Measles and Pertussis Associated With Personal Exemptions to Immunization, 284 JAMA 3145, 3149 (2000).

248. Linda E. LeFever, Note, Religious Exemptions from School Immunization: A Sincere Belief or a Legal Loophole?, 110 PENN ST. L. REV. 1047, 1048 (2006).

249. Id. 
vaccinations . . .."250 A survey conducted by Orenstein's Agency suggests "that more than 90 percent of all American children have had most shots, except for the new chicken-pox vaccine."251 A study in the American Journal of Public Health found that,

$[\mathrm{H}]$ ow many children receive the exemptions depends partly on how much red tape is involved .... In states where parents must go to a state office for exemption forms, get their signatures notarized or produce letters from a religious authority, exemption rates tend to be lower. ${ }^{252}$

Moreover, in all but a handful of jurisdictions, requests for exemptions are neither seriously documented nor verified. ${ }^{253}$ Often, the law requires a parent to do no more than simply check a box indicating that he or she does not want to have his or her child receive a vaccination. ${ }^{254}$ This technique is employed in states such as Washington, California, and Colorado. ${ }^{255}$ As such, places like Vashon Island, Washington, have allowed eighteen percent of the primary school students' parents to legally opt out of vaccination against childhood diseases. ${ }^{256}$

The U.S. Supreme Court has never ruled on the constitutionality of religiously justified vaccination exemptions. ${ }^{257}$ However, similar case law indicates that mandatory immunization without religious exemptions does not violate a person's right to free exercise of religion. The Court in Employment Division v. Smith held that the Free Exercise Clause, assuming that it is not coupled with another constitutional right, cannot be used to challenge a law of general applicability unless it can be shown that the law was motivated by a desire to interfere with religion. ${ }^{258}$ As such, if a law is religion-neutral and generally applicable, it does not interfere with one's right to free exercise of religion. ${ }^{259}$

An argument could be made that if a State mandates Gardasil, it implicates the hybrid-rights exception from the Smith case. A parent opposed to her

250. McNeil, Jr., supra note 243, at A2.

251. Id.

252. Id. (quotation in original).

253. Calandrillo, supra note 115 , at 360 .

254. Id. If checking a box is not sufficient and documentation is required, one is welcome to join the Congregation of Universal Wisdom, whose tenets hold unnatural compositions (i.e., vaccines) shall not be injected into the body. The Congregation has over 5000 members to date, and it primarily consists of parents seeking exemptions to vaccination requirements. Id.

255. McNeil, Jr., supra note 243, at A2.

256. Id.

257. Salmon, supra note 192, at 2.

258. Emp. Div., Dep't of Human Res. of Or. v. Smith, 494 U.S. 872 (1990).

259. Id. 
child receiving the vaccine for religious reasons could argue that the state's mandate implicates the hybrid-rights exception because both the Free Exercise Clause and her right to direct the education of her child are being violated. Under the hybrid-rights exception, the Court in Smith held that strict scrutiny should be applied in this situation. However, this exception should not apply since courts have not applied this exception uniformly. ${ }^{260}$ Several courts have interpreted the "hybrid-rights" exception as mere dicta and not applied strict scrutiny analysis. ${ }^{261}$ In Leebaert v. Harrington, the Court refused to apply strict scrutiny analysis when the plaintiff claimed that compelling his child to attend health classes violated both his Free Exercise rights and his constitutional right to direct the upbringing of his child. The Court refused to apply strict scrutiny analysis for the following reasons:

1) the Court in Smith did not decide the case upon the hybrid-rights theory, 2) [the First, Ninth, Tenth, and D.C. Circuits, which] claim the hybrid-rights theory warrants strict scrutiny have yet to apply strict scrutiny; and 3) adjudication of rights under the Free Exercise Clause should not change because other constitutional rights are involved. ${ }^{262}$

As such, mandating the Gardasil vaccination for all females in school is a religion-neutral law and generally applicable.

Indeed, no religious motivations accompany the states' requirement that all children receive the Gardasil vaccination. The health and safety of the community as a whole is the sole motivation for requiring the vaccination. Therefore, although clusters of parents may be opposed to state mandated Gardasil vaccinations, due to religious beliefs regarding the administration of shots in general or because they believe it will promote premarital sexual activity, those beliefs should not be a factor in the states' decision to require those females not subject to non-medical exemptions to be vaccinated with Gardasil. Moreover, the states' mandated vaccination is generally applicable even though the shot is only available to females. Currently, the shot is only available for females, but the manufacturer is conducting experiments to determine whether or not the vaccine is safe for males. If the vaccination is proven effective for males, states should require that everyone, females and males, be vaccinated with Gardasil.

If states mandate the Gardasil vaccination but allow for non-medical exemptions, it poses a threat to public safety, which defeats the vaccination's purpose. Clusters of unvaccinated children are not only a potential danger to

260. Jack Peterson, Note, Exceptions to Employment Division v. Smith: A Need for Change, 10 LEWIS \& CLARK L. REV. 701, 710 (2006).

261. Id.

262. Id. at 713 . 
themselves, but they are also a threat to the "herd immunity" that walls out epidemics. ${ }^{263}$ "[T] on the health care system in dealing with the outbreaks that do occur." ${ }^{264}$ Clearly, the state should strive to maintain a zero tolerance policy for societal risks resulting from exemptions. Indeed, the elimination of all exemptions to compulsory vaccinations, would be the most effective means of preventing many possible cases of cervical cancer and/or genital warts. Thus, in order to provide the greatest benefit for the greatest number of individuals, only medical exemptions should be allowed by the various states.

\section{CONCLUSION}

Relevant case law indicates that it is constitutional for states to mandate the Gardasil vaccine for all females entering the sixth grade. Even though booster shots may be required and annual Pap tests should still be conducted, the vaccination is a benefit to the society as a whole. The fact that HPV is not transmitted through casual contact is not reason enough to continue allowing thousands of women to die annually, as a result of cervical cancers resulting from HPV infection, when Gardasil has the potential to save their lives. Moreover, requiring the administration of the vaccine does not encourage females to engage in sexually promiscuous activity. No studies can substantiate that claim. Instead, females can take the opportunity to discuss the vaccine with their parents and doctor to realize the dangers of sexual promiscuity. Additionally, by requiring every eleven year-old girl to receive the vaccine, the mandate is not arbitrary. Indeed, states are looking out for their citizens' best interests by requiring the vaccination because Gardasil could potentially save 3700 U.S. women annually from death caused by cervical cancer.

In the past, states have permitted parents to claim non-medical exemptions to mandated vaccinations. However, such exemptions should not be allowed for the Gardasil vaccination. Indeed, there is no constitutional basis for exemptions to vaccinations. Also, states should strive to maintain the most effective vaccination program possible. Evidence shows that by allowing check-box opt out provisions for religious or philosophical reasons, universal coverage is not achieved. Historically, states have not actively verified all of the philosophical and religious exemptions for prior vaccines, which in turn make the opt-out provisions merely a convenience exemption for parents. Since this opt out provision is a convenience for parents, evidence reflects that these provisions have been abused. Moreover, the right to practice religion freely does not include the liberty to expose the community or a child to disease. Therefore, based on the overriding interest in the community's health and safety, non-medical exemptions to the Gardasil vaccine should not be allowed. 
